\title{
Surface-Enhanced Raman Spectroscopy And Density Functional Theory Study Of Glyphosate And Aminomethylphosphonic Acid Using Silver Capped Silicon Nanopillars
}

Rozo, Ciro; Wu, Kaiyu; Rindzevicius, Tomas; Boisen, Anja; Castillo, John J.

Published in:

Universitas Scientiarum

Link to article, DOI:

10.11144/Javeriana.SC26-1.srsa

Publication date:

2021

Document Version

Publisher's PDF, also known as Version of record

Link back to DTU Orbit

Citation (APA):

Rozo, C., Wu, K., Rindzevicius, T., Boisen, A., \& Castillo, J. J. (2021). Surface-Enhanced Raman Spectroscopy And Density Functional Theory Study Of Glyphosate And Aminomethylphosphonic Acid Using Silver Capped Silicon Nanopillars. Universitas Scientiarum, 26(1), 51-66. https://doi.org/10.11144/Javeriana.SC26-1.srsa

\section{General rights}

Copyright and moral rights for the publications made accessible in the public portal are retained by the authors and/or other copyright owners and it is a condition of accessing publications that users recognise and abide by the legal requirements associated with these rights.

- Users may download and print one copy of any publication from the public portal for the purpose of private study or research.

- You may not further distribute the material or use it for any profit-making activity or commercial gain

- You may freely distribute the URL identifying the publication in the public portal 


\title{
Surface-enhanced Raman Spectroscopy and Density Functional Theory Study of Glyphosate and Aminomethylphosphonic acid Using Silver Capped Silicon Nanopillars
}

\author{
Ciro Rozo $^{1}$, Kaiyu Wu ${ }^{2}$, Tomas Rindzevicius ${ }^{2}$, Anja Boisen ${ }^{2}$, John J. Castillo ${ }^{* 3,4}$
}

\section{Edited by}

Juan Carlos Salcedo-Reyes

salcedo.juan@javeriana.edu.co

1. Grupo de Investigaciones Ambientales para el Desarrollo Sostenible, Facultad de Química Ambiental, Universidad Santo Tomas, Floridablanca, Colombia.

2. Department of Health Technology, Technical University of Denmark, Lyngby, Denmark.

3. Grupo de Investigación en Bioquímica y Microbiología GIBIM, Universidad Industrial de Santander, Bucaramanga, Colombia.

4. Laboratorio de Espectroscopia Atómica y Molecular LEAM, Universidad Industrial de Santander, Bucaramanga, Colombia.

*jcasleon@uis.edu.co

Received: 01-04-2020

Accepted: 01-03-2021

Published online: 18-05-2021

Citation: Rozo C, Wu K, Rindzevicius T, Boisen A, Castillo JJ. Surface-enhanced Raman Spectroscopy and Density Functional Theory Study of Glyphosate and Aminomethylphosphonic acid Using Silver Capped Silicon Nanopillars, Universitas Scientiarum, 26(1): 51-67, 2021. doi: $10.11144 /$ Javeriana.SC26-1.srsa

Funding: Danish National Research Foundation (Project DNRF122) and Villum Fonden (Grant No. 9301) and Santo Tomas University (Project GIFQCAAMBECONP32017).

Electronic supplementary material: N.A.

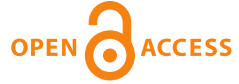

\begin{abstract}
Glyphosate (GP) is a broad-spectrum systemic herbicide which is used for killing a wide variety of harmful plants. Several recent studies indicate possible adverse health effects on humans. This work is focused on detection and adsorption studies of GP and its metabolite aminomethylphosphonic acid (AMPA) on silver-capped silicon nanopillars using surface-enhanced Raman spectroscopy (SERS). Density Functional Theory with the B3LYP functional was employed for the geometry optimization of ground state geometries and simulation of Raman and SERS spectra of the GP and AMPA. The theoretically calculated and experimentally observed vibrations of GP and AMPA free and attached to the Ag surface exhibited different Raman spectra revealing chemical interactions between the analysed molecules and the metal surface. DFT studies confirmed that the main $\mathrm{Ag}-\mathrm{GP}$ interaction is with the oxygen from carboxylic and phosphate groups, and for AMPA the main interaction is via a strong interaction between nitrogen from $\mathrm{NH}$ with the metal surface. In order to study the binding behavior, adsorption isotherm analysis between GP and AMPA on silver-capped silicon nanopillars (AgNPs) were performed. Finally, the obtained isotherms for GP and AMPA followed a negative cooperative binding mechanism.
\end{abstract}

Keywords: Glyphosate; AMPA; SERS; silver nanopillars; adsorption; DFT.

\section{Introduction}

GP (N-(phosphonomethyl) glycine), is one of the most used commercial herbicides in the world. It is a non-selective herbicide of systemic action, broad spectrum, post-emergent action, which has no residual effect and is soluble in water [1]. The action mechanism of glyphosate starts when it is taken up by the foliage of plants, and it is transported through the plant resulting in its death after several days. Currently, there are more than 91 manufacturer companies distributed in 20 countries, and GP is probably the most heavily used herbicide worldwide, with an annual global production volume estimated at approximately $720000 \mathrm{t}$ in 2017 [2].

GP can be found in air, soil, foods, surface water and groundwater. Once in the environment, glyphosate is adsorbed to soil and is broken down by soil microbes to aminomethylphosphonic acid (AMPA), the main glyphosate metabolite responsible for crop damage upon glyphosate application [3]. AMPA is structurally like glyphosate and it shares similar properties in terms 
of behavior and toxicity. Thus, these species directly pollute the environment, contaminate foods and enter the human body. GP residues have been measured in cereals, fruits, and vegetables [4]. Residues were detected in $0.04 \%$ of 74 samples from 305 total food samples analysed. In recent years there is controversy about its potential unfavourably health effects on humans. Several studies have shown the harmful effects of glyphosate and AMPA [5], for example [6] study the effects of GP intoxication on farming population, showing that glyphosate is highly toxic because of the multiple organ compromise in the human body. Genotoxicity studies of AMPA in human lymphocytes were carried out in [4]. A statistically significant clastogenic effect of AMPA at $1.8 \mathrm{mM}$ concentration compared with a control group was found. Recently, the article [7] found a minor evidence for negatives effects following exposure to GP on levels of depression, anxiety, and neural disorders. However, in the same study they found a connection between exposure to this herbicide at work to Parkinson's and Alzheimer's later in life. They concluded that exposure to glyphosate used in aerial spraying increases the number of medical consultations related to dermatological and respiratory illness, as well as the number of spontaneous abortions. Other adverse effects of glyphosate include massive decline in insect populations that affect diversity of species, disruption of plant pollination and damage to ecosystems that could also produce significant agricultural problems. Several EU countries have introduced major restrictions for using the controversial weed killer, e.g. the Czech Republic, Italy, and the Netherlands. Austria has recently outlawed glyphosate while Germany and France plan to ban its use by the end of $2023[8]$.

Determination of pesticide residues is essential in regulating and monitoring levels of pesticides. Therefore, detection of GP and AMPA requires the development of reliable analytical methods and rapid response that provide a timely response. Traditionally, the analytical methods for the detection of pesticides usually employ equipment that measure permissible levels of pesticides; among these methods are high-performance liquid chromatography (HPLC), thin-layer chromatography (TLC), gas chromatography-mass spectrometry (CG-MS) and immunoassays-based detection techniques $[3,5,9]$. Although, these methods are effective for this purpose due to their highly sensitive and accurate detection, they have disadvantages such as complex clean-up process, multiple derivative operation steps, being time consuming and expensive. The absence of a detectable functional group in glyphosate molecule makes it difficult to measure glyphosate by conventional detectors such as UV-vis or diode arrays. Therefore, there is a need for a simple, cheap and potentially portable technique for on-site detection of GP.

Surface-enhanced Raman spectroscopy (SERS) is an analytical vibrational spectroscopy which has been widely used to detect trace amounts of target molecules situated in close vicinity (within a few $\mathrm{nm}$ ) to a nanostructured noble metal surface. SERS technique is also suitable for detecting pesticides in aqueous solution. For example, detection of trace amounts of GP using silver nanocubes aqueous suspensions combined with DFT computation methods was first reported in [10]. In this approach they employed SERS with DFT computational methods to detect GP at trace level by using silver nanocubes aqueous suspensions. In a similar study, [11, 12] a SERS substrate of dendritic silver nanostructures on carbon coated $\mathrm{Ag}-\mathrm{Cu}$-grids was developed for glyphosate detection. The paper [13] synthesized gold nanorods derivatized with 4-mercapto phenylboronic acid in order to achieve attomole detection of glyphosate in samples of tomato juice. On the other hand, in [14] a highly sensitive SERS substrate based on Os-AuNPs reaching a detection limit of $0.1 \times 10^{-6} \mathrm{~g} \mathrm{~L}^{-1}$ was fabricated; however, osmium is relatively expensive with potential toxicity to humans. The vibrational analysis 
of the herbicide diquat adsorbed on silver nanoparticles was first studied study using SERS and DFT methods [15]. The paper [16] studied the adsorption behavior of three herbicides (atrazine, prometryn and simetryn) using both SERS and Raman techniques together with theoretical calculations (B3LYP/aug-cc-pVQZ). A novel method for indirect detection of glyphosate based on ninhydrin reaction and SERS was developed in [1]. They reached a limit detection of $1.43 \times 10^{-8} \mathrm{~mol} \mathrm{~L}^{-1}$ with a wide lineal concentration range $\left(1 \times 10^{-7} \mathrm{~mol} \mathrm{~L}^{-1}\right.$ to $1 \times 10^{-4} \mathrm{~mol} \mathrm{~L}^{-1}$. A dispersion of silver nanoparticles was used to study the orientation of $13 \mathrm{C}$ glyphosate isotope substituted derivate, and its degradation product, AMPA. SERS studies allowed to conclude that the differences both on the intensities and wave numbers SERS and Raman spectra of glyphosate must derive from the effect induced by the adsorption on the nanoparticles [17]. The paper [18] studied chemical interaction between phosphonate derivate-molecules and silver surface cluster by a combined experimental and computational approach, concluding that changing functional group is important to modulate the chemical interactions between different functions and the metal cluster in order to design analytical devices based on SERS techniques. In another study, the article [19] developed a novel in situ colorimetric assay to detect GP on plant tissues using cysteamine-modified gold nanoparticles. A color change from red to blue was observed directly on the surface plan tissue, achieving GP concentrations as low as $1 \mu \mathrm{g} \mathrm{L}-1$.

There are no previous SERS and DFT studies focused on the adsorption behavior of GP and AMPA in nanostructured metallic surfaces. Therefore, this study presents the results of the adsorption of GP herbicide and its metabolite AMPA on silver metal nanostructures using SERS combined with quantum chemical calculations. To investigate the interaction of GP with nanostructured silver, SERS-active silver-capped silicon nanopillar (AgNP) substrates were utilized. The DFT method was employed to optimize ground state geometries and simulation of Raman spectra of the GP. Finally, the binding properties of GP and AMPA molecules on the AgNP surface was studied, using different GP and AMPA concentrations.

\section{Materials and methods}

\subsection{Raman measurements}

All spectra were measured using a Horiba scientific LabRam HR evolution (Yobim Yvon, USA) in a range from $50 \mathrm{~cm}^{-1}$ to $4000 \mathrm{~cm}^{-1}$. A $53 \mathrm{~nm}$ laser excitation $(25 \mathrm{~mW})$ and a diffraction grating of 600 lines $\mathrm{mM}^{-1}$ were used. Raman spectrum of GP was measured using a $50 \times$ objective and the acquisition time was $30 \mathrm{~s}$ for 1 accumulation. Glyphosate and AMPA SERS spectra adsorbed on AgNPs were recorded using a 50× objective, $0.1 \mathrm{~mW}$ laser power and $5 \mathrm{~s}$ signal accumulation time.

\subsection{Fabrication of SERS nanopillars}

The Ag NP were fabricated using a four-step process. First, a maskless Si reactive ion (RIE) etching was employed, as well as and silver metal deposition method processes yielding vertical freestanding to obtain the silver-capped silicon nanopillar structures (AgNP) surrounded with a silver film at the base of the pillars. Second, an $\mathrm{O}_{2}$ plasma process is applied to remove Si RIE by-products from the Si surface, and control the AgNP size. Third, a Cr adhesion layer is evaporated onto the SiNP structure. Finally, an Ag metal film is deposited onto the $\mathrm{Si}$ NPS using e-beam evaporation. The obtained Ag NP density is approximately 18 pillars $/ \mu \mathrm{m}^{2}$. AgNP dimensions are the followings: AgNP height $\sim 600 \mathrm{~nm}$, Si pillar width $\sim 50 \mathrm{~nm}$, 
Ag cap height and width are $\sim 300 \mathrm{~nm}$ and $\sim 120 \mathrm{~nm}$, respectively. The thickness of the evaporated Ag metal film is $225 \mathrm{~nm}$. Ag NP structured were stored in a desiccator and used within 3 days to minimize any effects related to oxidation of the Ag surface.

\subsection{SEM characterization}

SEM pictures were obtained from a Zeiss Ultra Plus field SEM microscope equipped, and the accelerating voltage was $8 \mathrm{kV}$. The cross-sectional images were taken at a tilted angle of $5^{\circ}$ and $45^{\circ}$ respectively.

\subsection{Numerical simulation}

COMSOL MULTIPHYSICS version 5.4 was used for SEM calculations in order to achieve a reasonable computation time, and ellipsoids were used to approximate the silver caps. Silicon pillars were modeled by cylinders with arched tops. A perfect matched layer was employed to eliminate nonphysical reflections. The boundary conditions for the side planes of both the solution domain and the perfect matched layer were Floquet periodicity. Materials were modeled by their complex refractive indices as functions of wavelength [20, 21].

\subsection{Preparation of glyphosate and AMPA solutions}

Glyphosate was commercially purchased from Sigma-Aldrich Corp. The GP $(0.0156 \mathrm{~g})$ was incubated with type $\mathrm{I}_{2} \mathrm{O}(1.5 \mathrm{~mL})$ and magnetically stirred until all glyphosate dissolved. Serial dilutions in a range between $1 \times 10^{-3}$ and $1 \times 10^{-8}$ were prepared from the stock glyphosate solution. A similar procedure was employed for preparing AMPA solutions.

\subsection{Raman and SERS measurements}

Solid powder ( $c a .1 \mathrm{mg}$ ) of GP and AMPA were deposited on a silicon surface in order to obtain the normal Raman scattering spectra. A $1 \mu \mathrm{L}$ of a freshly prepared solution was putted on the AgNP SERS substrates and left to dry for 10 min to provide homogeneity in surface coverage. AgNPs containing glyphosate was rinsed with Milli-Q water and dried with nitrogen in order to remove the non-adsorbed species before every SERS measurement. The Raman signal was recorded over an area of $0.05 \mathrm{mM}^{2}$ with $x=17 \mu \mathrm{m}$ and $y=11 \mu \mathrm{m}$ step sizes.

\subsection{Computational methods}

The calculations were performed using the program package Gaussian 09 [11]. DFT method, using the Becke three-parameter Lee-Yang-Parr (B3LYP) theory combined with the standard 6-31G(d) basis was used to optimize ground state geometries. The GaussSum 3.0 software was then used to plot theoretical Raman scattering spectra [22]. All calculated frequencies were adjusted by a factor of 0.9614 to avoid systematic errors, in accordance with the reported results [23]. The interaction $\mathrm{GP}-\mathrm{Ag}$ and $\mathrm{AMPA}-\mathrm{Ag}$, as well as the geometry optimization of both molecules and vibrational spectra were calculated by means of the scalar relativistic effective core potential (ECP) with double-zeta basis set (LANL2DZ) [24]. To avoid difficulties and delays in computational calculations for larger clusters, a cluster of 10 $\mathrm{Ag}$ atoms ( $\mathrm{Ag} 10)$ was chosen to simulate the $\mathrm{GP}-\mathrm{Ag}$ and $\mathrm{AMPA}-\mathrm{Ag}$ vibrational spectra [25], i.e., $\mathrm{GP}-\mathrm{Ag} 10$ and $\mathrm{AMPA}-\mathrm{Ag} 10$ (Figure 4). 


\section{Results and Discussion}

Figure 1 shows the DFT-optimized molecular structures of GP and AMPA. The structure optimization study exhibited three stable possible GP conformations (glyphosate 1, glyphosate 2 and glyphosate 3, Figure 1). GP 1 revealed a linear structure characterized by a dihedral angle $\left(\mathrm{CH}_{2}-\mathrm{NH}-\mathrm{CH}_{2}-\mathrm{C}=\mathrm{O}\right)$ of $285.4^{\circ}$ and a bond distance between $\mathrm{OPH}$ and $\mathrm{C}=\mathrm{O}$ of approximately $5.26 \AA$. On the other hand, glyphosate 2 conformation showed a longer bond distance $\mathrm{OPH}-\mathrm{CO}$ of $5.60 \AA$ and a dihedral angle of $191.8^{\circ}$. Glyphosate 3 configuration exhibited the most stable ground state geometry with an intramolecular interaction characterized by a hydrogen bond between $\mathrm{H}(\mathrm{POH})$ and oxygen from carboxylic group $(\mathrm{O}=\mathrm{COH})$ with a bond distance of $1.81 \AA$. Table 1 shows the energy values, bond distances and dihedral angle for the three GP configurations.

Due to the smaller molecular size of AMPA compared to that of glyphosate, it was possible to obtain a single ground state geometry configuration (Figure 1).

Solid state Raman and calculated spectrum of glyphosate at the B3LYP/6-31G** level of theory is shown in Figure 2A and Table 2. Most of experimentally observed glyphosate vibrational modes can also be found in the simulated Raman spectrum, see Figure 2A and Table 2. The measured solid-state Raman scattering spectrum of glyphosate is dominated by five strong vibrational modes at $1031 \mathrm{~cm}^{-1}, 920 \mathrm{~cm}^{-1}, 911 \mathrm{~cm}^{-1}, 764 \mathrm{~cm}^{-1}$ and $766 \mathrm{~cm}^{-1}$ which are mainly related to vibrations from $\mathrm{CH}_{2}, \mathrm{O}-\mathrm{P}-\mathrm{O}$ stretching and $\mathrm{NH}_{2}$, respectively. In addition, the Raman scattering peak located at $1076 \mathrm{~cm}^{-1}$ can be assigned to a weak $\mathrm{OH}$ rocking vibration. According to our theoretical analysis (Table 2 and Figure 2A), the Raman band observed at $1191 \mathrm{~cm}^{-1}$ could be attributed to a weak stretching vibration from $\mathrm{C}-\mathrm{OH}$.

On the other hand, the DFT results for AMPA show three strong Raman bands at $1017 \mathrm{~cm}^{-1}$, $928 \mathrm{~cm}^{-1}$ and $727 \mathrm{~cm}^{-1}$, which can be attributed to symmetric stretching vibrations from $\mathrm{C}-\mathrm{H}$ and $\mathrm{C}=\mathrm{O}$ functional groups and an asymmetric stretching vibration from $\mathrm{P}-\mathrm{C}$ bond, respectively (Figure $2 \mathrm{~b}$ ). These values correlate well with those obtained in [26]. The Raman bands located around $865 \mathrm{~cm}^{-1}$ and $809 \mathrm{~cm}^{-1}$ are directly related to those frequencies of the $\mathrm{OH}$ groups around the phosphorus atom, providing potential fingerprint signals for detection of AMPA. Only ca. $8 \%$ of the Raman signals do not agree with some bands, even though the

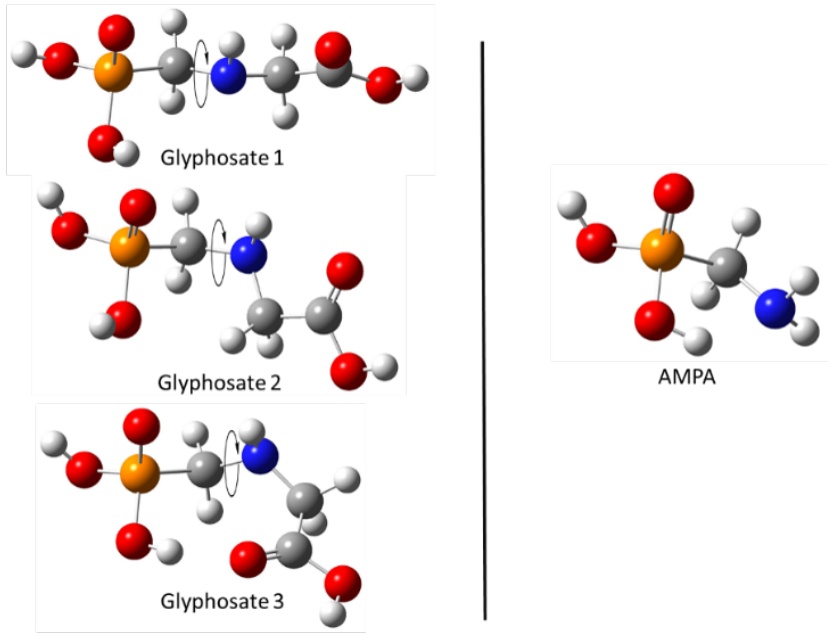

Figure 1. Optimized structures of glyphosate and AMPA. 
Table 1. Energies values, bond distances and dihedral angles for glyphosate configurations.

\begin{tabular}{lccc}
\hline Configuration & $\begin{array}{c}\text { Energy } \\
\left(\mathrm{kcal} \mathrm{mol}^{-1}\right)\end{array}$ & $\begin{array}{c}\text { Bond distance }(\AA) \\
(\mathbf{C}=\mathbf{O}-\mathbf{H O P})\end{array}$ & $\begin{array}{c}\text { Dihedral angle } \\
\left(\mathbf{C H}_{\mathbf{2}}-\mathbf{N H}-\mathbf{C H}_{\mathbf{2}}-\mathbf{C}=\mathbf{O}\right)\end{array}$ \\
\hline Glyphosate 1 & -559375.11 & 5.26 & 285.39 \\
Glyphosate 2 & -559375.01 & 5.60 & 191.82 \\
Glyphosate 3 & -559378.43 & 1.81 & 165.43 \\
\hline
\end{tabular}

calculated frequencies were corrected by a factor of 0.9614 . Nonetheless, the most intense bands from the calculated Raman spectrum are also present in the experimentally obtained Raman scattering spectrum of AMPA (Table 2).

A SEM image of the Ag NP SERS substrate is shown in Figure 3A. After introducing the analyte solution to the substrate surface, during solvent drying, surface tension pulls the adjacent NPs together, forming micro sized Ag NP clusters, see Figure 3B. The Ag NP cluster formation simultaneously traps analyte molecules and generates the electromagnetic hot spots in the nanogaps between the Ag caps, which is shown by the simulated electrical field enhancement distribution in Figure 3C.

Figure 4A shows the experimental SERS spectrum of GP adsorbed on Ag NPs and calculated Raman spectra of GP adsorbed on AgNP (GP - Ag10) at the B3LYP/6-31G level of theory, see the geometry in Figure 5A. It is observed that the GP-Ag10 spectrum differs notably from the GP solid-state Raman spectrum, owing to the specific selection rules and to the proximity of GP structure to the metal surface [27]. Table 3 shows the main vibrational Raman bands with its respective DFT-based assignment for GP molecule.

A significantly increased intensity of the Raman signal located at $1591 \mathrm{~cm}^{-1}$ attributed to a symmetric vibration of $\mathrm{C}=\mathrm{O}$ is observed. The relative intensities from the SERS signals are expected to differ significantly from those of normal Raman signals [26]. For example,

Table 2. Experimental and DFT-Calculated vibrations Raman modes for glyphosate and AMPA molecules.

\begin{tabular}{|c|c|c|c|c|c|}
\hline \multicolumn{3}{|c|}{ Glyphosate } & \multicolumn{3}{|c|}{ AMPA } \\
\hline Experimental & Calculated & Assignments & Experimental & Calculated & Assignments \\
\hline- & 1561 & $v(\mathrm{C}=\mathrm{O})$ & 1644 & 1629 & $s(\mathrm{NH})$ \\
\hline 1467 & 1463 & $s\left(\mathrm{CH}_{2}\right)$ & 1524 & - & - \\
\hline 1448 & 1421 & $\rho(\mathrm{NH})$ & 1436 & 1446 & $s\left(\mathrm{CH}_{2}\right)$ \\
\hline 1381 & 1340 & $\omega\left(\mathrm{CH}_{2}\right)$ & 1415 & - & - \\
\hline 1300 & - & $\rho(\mathrm{OH}) \mathrm{COOH}$ & 1344 & - & - \\
\hline 1267 & 1286 & $\omega\left(\mathrm{CH}_{2}\right)+\rho(\mathrm{OH})$ & 1314 & 1329 & $\rho(\mathrm{NH})+\omega(\mathrm{CH})$ \\
\hline 1246 & - & $v\left(\mathrm{CH}_{2}\right)+\omega\left(\mathrm{CH}_{2}\right)$ & - & 1262 & $\rho(\mathrm{CH})$ \\
\hline 1226 & 1230 & $\tau\left(\mathrm{CH}_{2}\right)$ & - & 1230 & $\omega\left(\mathrm{CH}_{2}\right)$ \\
\hline 1174 & 1191 & $\tau\left(\mathrm{CH}_{2}\right)+\rho(\mathrm{OH}) \mathrm{COOH}$ & 1150 & 1164 & $\rho(\mathrm{OH})$ \\
\hline 1135 & 1128 & $\mathrm{a} v(\mathrm{C}-\mathrm{N}-\mathrm{C})$ & 1082 & 1075 & $\tau\left(\mathrm{CH}_{2}\right)$ \\
\hline 1053 & 1077 & $\mathrm{a} v(\mathrm{C}-\mathrm{N}-\mathrm{C})+\tau\left(\mathrm{CH}_{2}\right)$ & 1050 & 1029 & $\rho(\mathrm{OH})$ \\
\hline 1029 & 1031 & $\rho(\mathrm{OH}) \mathrm{HOP}=\mathrm{O}$ & 1017 & 1015 & $s v(\mathrm{C}-\mathrm{H})+\rho(\mathrm{OH})$ \\
\hline 1008 & 988 & $\rho(\mathrm{OH}) \mathrm{HOP}=\mathrm{O}$ & 928 & 920 & $\omega(\mathrm{NH})+\mathrm{s} v(\mathrm{C}=\mathrm{O})$ \\
\hline 899 & 927 & $\rho\left(\mathrm{CH}_{2}\right)$ & 865 & 889 & $\mathrm{a} v(\mathrm{HO}-\mathrm{P}-\mathrm{OH})$ \\
\hline 882 & 911 & $v(\mathrm{PO})$ & 823 & 834 & $\rho\left(\mathrm{CH}_{2}\right)+\rho(\mathrm{NH})$ \\
\hline 850 & 920 & $v(\mathrm{PO})$ & 759 & 794 & $\rho\left(\mathrm{CH}_{2}\right)+\mathrm{s} v(\mathrm{HO}-\mathrm{P}-\mathrm{OH})$ \\
\hline 818 & 857 & $v(\mathrm{PO})+\rho(\mathrm{OH}) \mathrm{HOP}=\mathrm{O}$ & 727 & 680 & $\mathrm{a} v(\mathrm{P}-\mathrm{C})$ \\
\hline 776 & 794 & $\rho(\mathrm{NH})$ & 710 & 628 & $\rho(\mathrm{OH})$ \\
\hline 714 & 766 & $\mathrm{a} v\left(\mathrm{PCH}_{2}\right)$ & & & \\
\hline
\end{tabular}



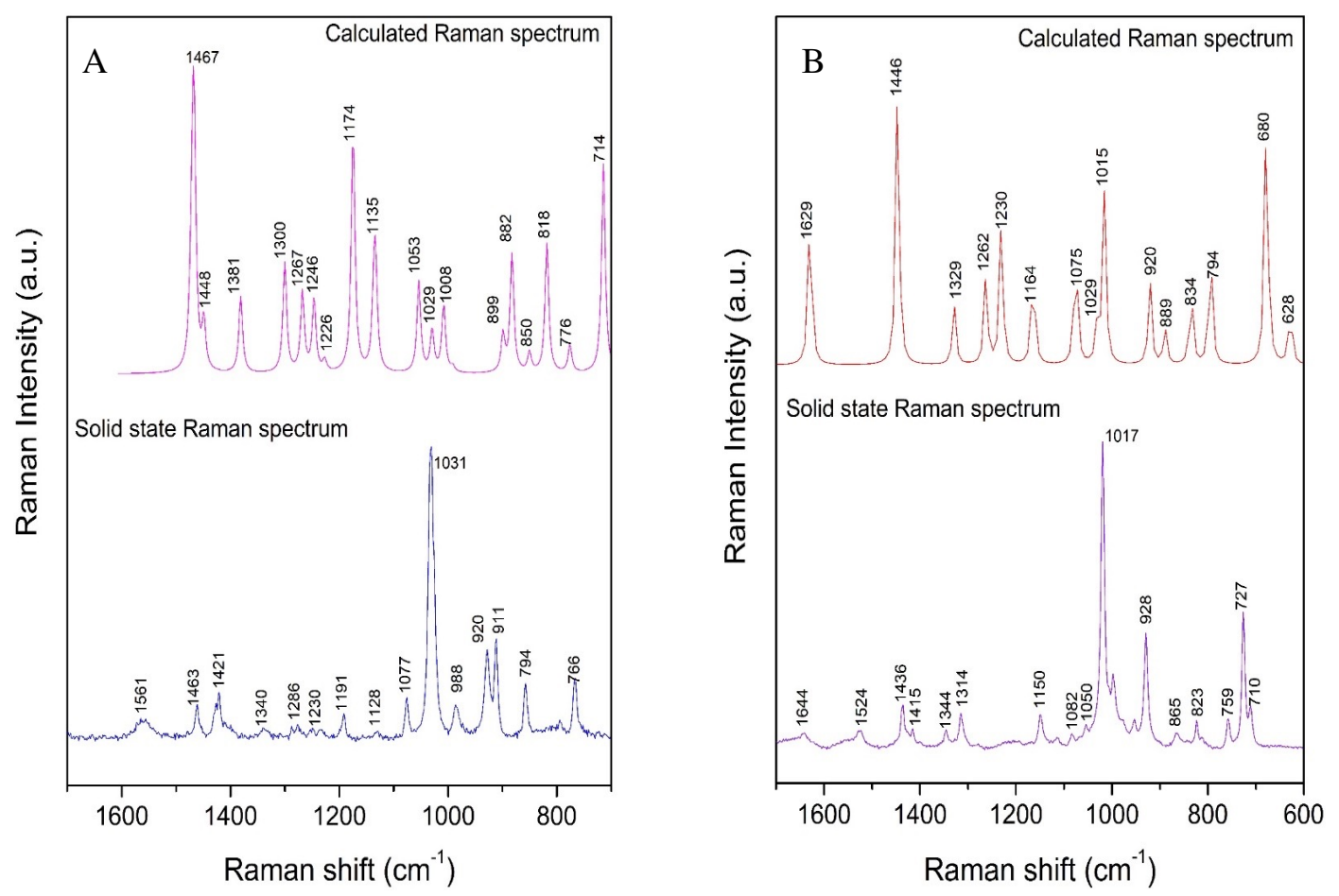

Figure 2. Simulated and experimental Raman spectra of solid-state glyphosate (Laser excitation: $532 \mathrm{~nm})(\mathrm{A})$ and AMPA (B).

the GP SERS vibrational modes observed at $1319 \mathrm{~cm}^{-1}, 1136 \mathrm{~cm}^{-1}$ and $705 \mathrm{~cm}^{-1}$ are likely due to the interaction between GP and silver metal (AgNPs). Interestingly, the Raman signal at $705 \mathrm{~cm}^{-1}$ arise mainly from a rocking vibration of the hydroxyl group $(\mathrm{O}-\mathrm{H})$ bounded to the phosphorus atom. The presence of an additional rocking vibration of $\mathrm{OH}$ located at
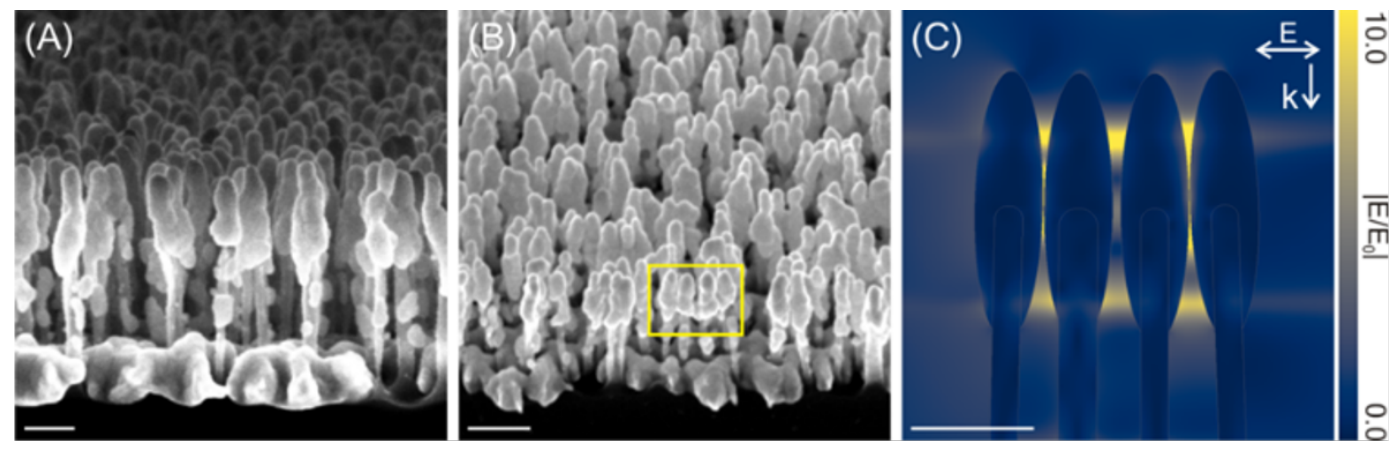

Figure 3. (A,B) Cross-sectional SEM images of silver capped silicon nanopillars that are (A) vertical, and (B) aggregated. The images are taken at a tilted angle of $5^{\circ}$ for $(A)$ and $45^{\circ}$ for $(B)$, respectively. The aggregation is caused by the capillary force during the evaporation of analyte solvent. (C) Simulated electric field enhancement distribution for aggregated silver capped silicon nanopillars. The structures are modeled according to those in the yellow box in (B). The excitation wavelength is $532 \mathrm{~nm}$, same as that for the SERS measurements. As is shown, the minimum nanogap distance is $2 \mathrm{~nm}$. An electrical field enhancement of $\sim 100$ was obtained. Scale bars: $200 \mathrm{~nm}$. 
Table 3. Experimental and DFT-Calculated vibrations SERS modes for glyphosate and AMPA molecules. av: asymmetric stretching; $s v$ : symmetric stretching; $\rho$ : rocking; $\omega$ : wagging; $\tau$ : twisting; $s$ : scissoring

\begin{tabular}{|c|c|c|c|c|c|}
\hline \multicolumn{3}{|c|}{ Glyphosate } & \multicolumn{3}{|c|}{ AMPA } \\
\hline Experimental SERS & Calculated & Assignments & Experimental SERS & Calculated & Assignments \\
\hline 1591 & 1611 & $v(\mathrm{C}=\mathrm{O})$ & 1580 & 1617 & $s(\mathrm{NH})$ \\
\hline- & 1482 & $\rho(\mathrm{NH})$ & 1377 & 1407 & $s\left(\mathrm{CH}_{2}\right)$ \\
\hline- & 1426 & $s\left(\mathrm{CH}_{2}\right)$ & 1277 & 1307 & $\rho(\mathrm{NH})+\rho(\mathrm{CH})$ \\
\hline 1389 & 1402 & $\rho(\mathrm{CH})$ & 1171 & 1118 & $\mathrm{sv}(\mathrm{NH})$ \\
\hline 1319 & 1303 & $\omega\left(\mathrm{CH}_{2}\right)$ & 1143 & 1095 & $\tau\left(\mathrm{CH}_{2}\right)+\rho\left(\mathrm{CH}_{2}\right)$ \\
\hline 1271 & 1284 & $\tau\left(\mathrm{CH}_{2}\right)$ & 1052 & 998 & $\rho(\mathrm{OH})$ \\
\hline 1249 & 1266 & $\rho(\mathrm{OH})+\omega\left(\mathrm{CH}_{2}\right)$ & 991 & 965 & $\rho(\mathrm{OH})$ \\
\hline 1226 & 1224 & $\rho(\mathrm{NH})+\tau\left(\mathrm{CH}_{2}\right)$ & 942 & 925 & $\mathrm{~s} v(\mathrm{P}-\mathrm{O})+\rho(\mathrm{OH})$ \\
\hline 1136 & 1170 & $\rho(\mathrm{CH})+\tau\left(\mathrm{CH}_{2}\right)$ & 839 & 821 & $\rho\left(\mathrm{CH}_{2}\right)+\rho(\mathrm{NH})$ \\
\hline 1071 & 1074 & $\rho(\mathrm{OH}) \mathrm{COOH}$ & - & 727 & $\mathrm{a} v(\mathrm{HO}-\mathrm{P}-\mathrm{OH})$ \\
\hline 1033 & 1050 & $\rho(\mathrm{OH})+\rho\left(\mathrm{CH}_{2}\right)$ & 685 & 680 & $\mathrm{a} v(\mathrm{P}=\mathrm{O})$ \\
\hline 1013 & 1018 & $\rho(\mathrm{OH}) \mathrm{PO}$ & & & \\
\hline 991 & 961 & $\rho(\mathrm{OH}) \mathrm{PO}$ & & & \\
\hline 953 & 944 & $\rho\left(\mathrm{CH}_{2}\right)$ & & & \\
\hline 923 & 929 & $v(\mathrm{P}-\mathrm{O})+\rho(\mathrm{OH})$ & & & \\
\hline 889 & 872 & $\rho\left(\mathrm{CH}_{2}\right)+v(\mathrm{P}-\mathrm{O})$ & & & \\
\hline 830 & 826 & $v(\mathrm{C}-\mathrm{C})$ & & & \\
\hline 705 & 747 & $\mathrm{a} \nu(\mathrm{O}-\mathrm{P}-\mathrm{O})$ & & & \\
\hline
\end{tabular}

$830 \mathrm{~cm}^{-1}$ (Table 3) supports the fact that the GP is attached to the AgNP by an interaction with the $\mathrm{P}-\mathrm{OH}$ and with the carboxylic group $(\mathrm{C}=\mathrm{O})$ forming a kind of "princer" with the surface (Figure 4A).
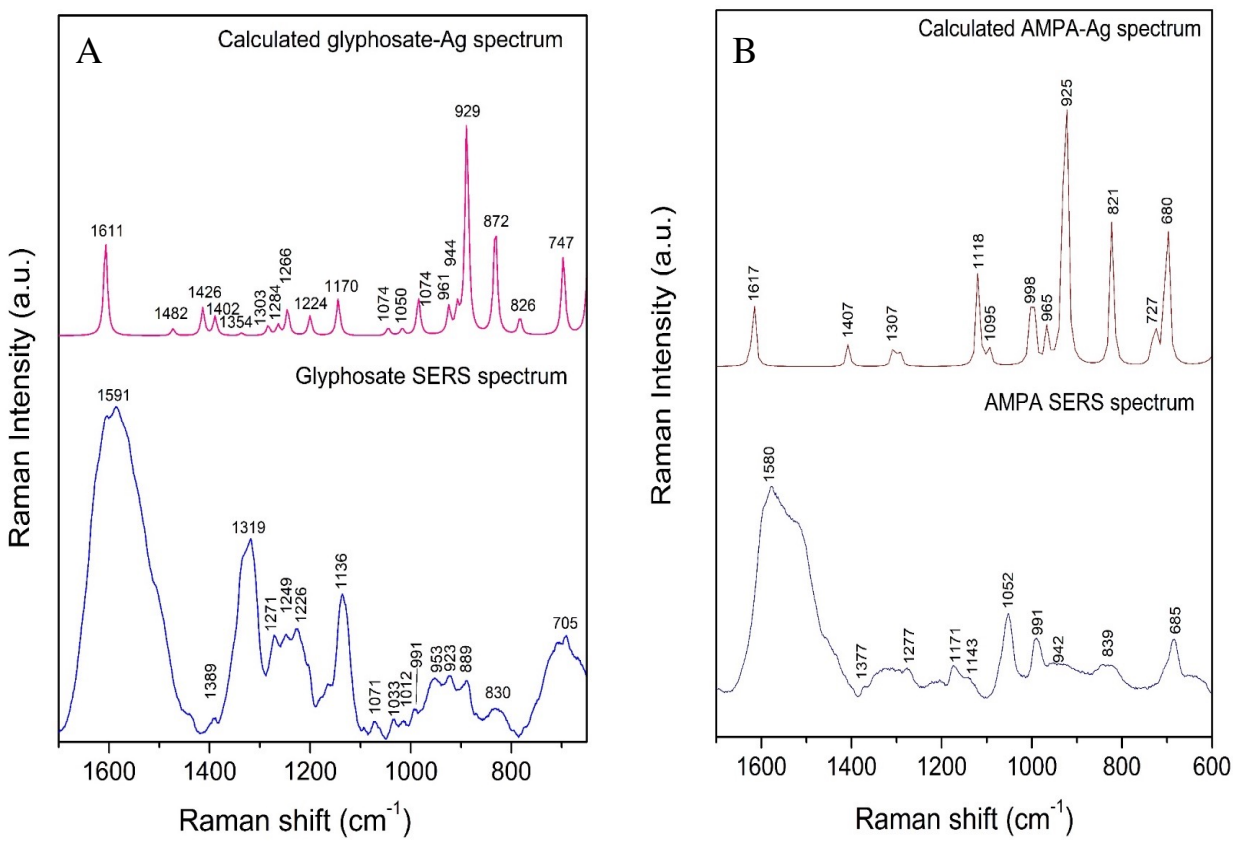

Figure 4. Simulated and experimental SERS spectra of glyphosate (Laser excitation: $532 \mathrm{~nm}$ ) (A) and AMPA (B). 

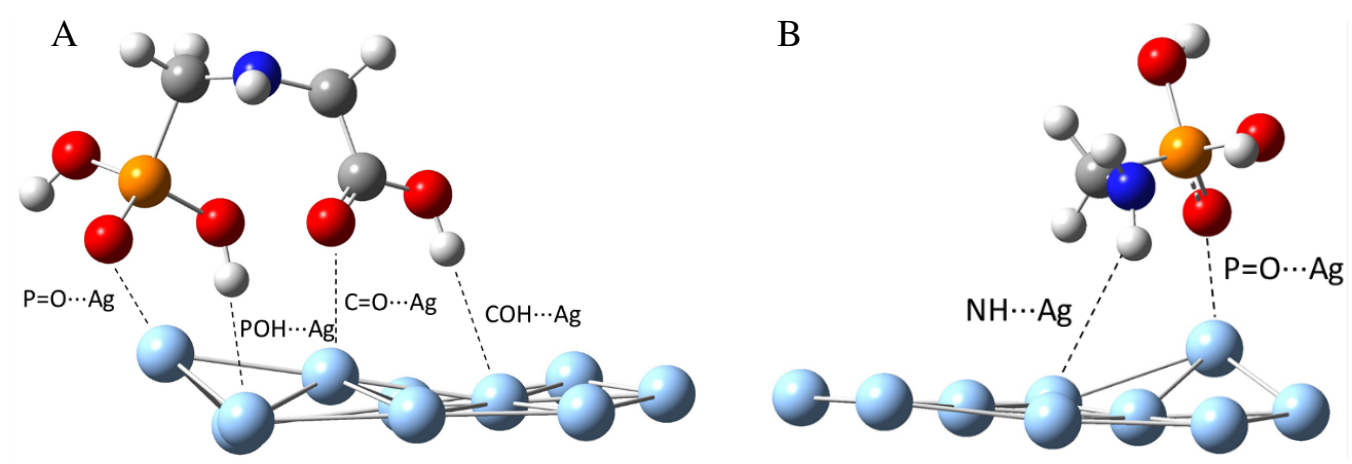

Figure 5. Optimized geometries of glyphosate (A) and AMPA (B) adsorbed on a cluster of 10 silver atoms.

The SERS spectrum of AMPA together with the simulated AMPA-Ag10 vibrational spectrum is shown in Figure 4B, and the most pronounced vibrational frequencies are listed in Table 3. The most important feature of AMPA SERS spectrum is the strong intensity of the $1580 \mathrm{~cm}^{-1}$ band, which is attributed to a strong interaction of the nitrogen $(\mathrm{NH})$ with the silver metal surface. A set of medium intense bands located at $1052 \mathrm{~cm}^{-1}, 991 \mathrm{~cm}^{-1}$ and $685 \mathrm{~cm}^{-1}$ correspond to rocking vibrations from $\mathrm{OH}$ groups and to an asymmetric vibration from $\mathrm{P}-\mathrm{O}$ bound. This set of vibrations are probably interacting in some way with the metallic surface in a lying down conformation.

This theoretical analysis suggests two adsorption models, the first one where the GP interacts mainly with the $\mathrm{Ag}$ atoms through the $\mathrm{OH}$ and $\mathrm{C}=\mathrm{O}$ groups and the second one where the AMPA interacts with silver through the nitrogen from $\mathrm{NH}$ group as shown in Figure 5. The adsorption of GP and AMPA on AgNPs was evaluated as a function of its concentration by means of the intensity of the symmetric stretching mode $\mathrm{C}=\mathrm{O}$ of the $\mathrm{GP}$ at $1611 \mathrm{~cm}^{-1}$ (calculated) and $1591 \mathrm{~cm}^{-1}$ (experimental), and the scissoring vibration mode at $1617 \mathrm{~cm}^{-1}$ (calculated) and $1580 \mathrm{~cm}^{-1}$ (experimental) for AMPA.

The intensity of the SERS signal is associated with the GP and AMPA adsorbed on the AgNP surface (Figure 6A and 6B). Figure 6C shows the concentration-dependent adsorption behavior of both molecules. The linear range for GP and AMPA were $1 \times 10^{-8}, 1 \times 10^{-6}$ and $1 \times 10^{-9}, 1 \times 10^{-6}$, respectively. On the other hand, the values of limit of detection (LOD) were $1 \times 10^{-8}$ and $1 \times 10^{-9}$ for GP and AMPA, respectively.

For marker peaks, $1589 \mathrm{~cm}^{-1}$ and $1580 \mathrm{~cm}^{-1}$ were selected for GP and AMPA, respectively. Experimental data are in good concordance with a nonlinear curve model from the Hill equation (3.1) [24].

$$
I_{\mathrm{SERS}}=\frac{I_{\mathrm{max}} \cdot B^{n}}{K_{\mathrm{ads}}+B^{n}}
$$

where $I_{\max }$ is the maximum registered SERS intensity, $B$ correspond to the concentration of glyphosate or AMPA solution, $K_{\text {ads }}$ is the equilibrium constant for dissociation and $n$ is a cooperative constant.

Cooperative constant gives information about attraction $(n>1)$ or repulsion $(n<1)$ between molecules adsorbed on AgNPs, and when $n=1$ the Hill equation is like the Langmuir isotherm. 

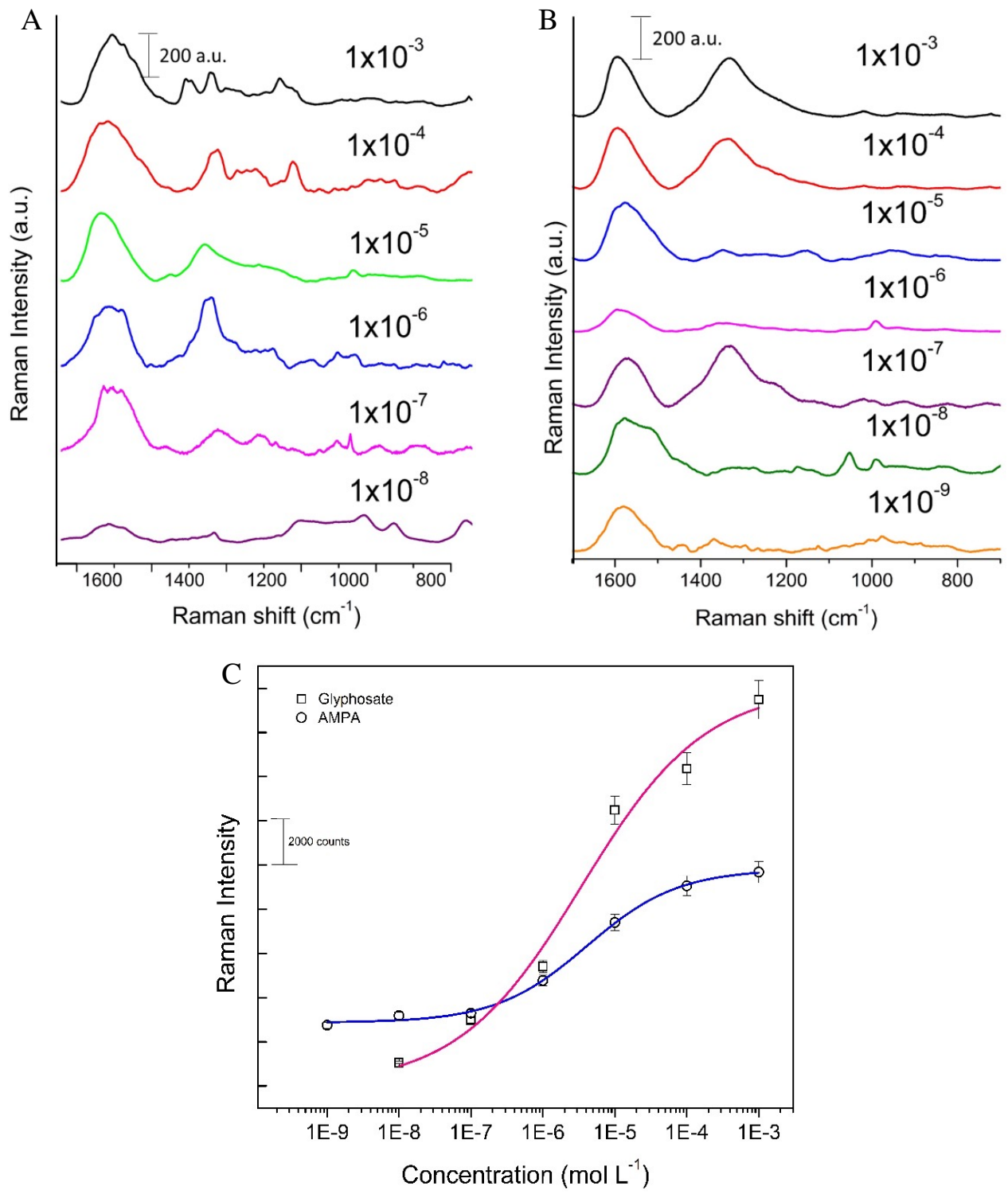

Figure 6. SERS spectra of different concentrations of glyphosate (A) and AMPA (B) adsorbed on silver-capped silicon nanopillars and SERS adsorption isotherms of glyphosate and AMPA (C). (The error bars were obtained from at least two measurements on three different locations on the same chip).

Table 4 shows the values for $K_{\text {ads }}$ and $n$ for glyphosate and AMPA molecules, clearly indicating that the adsorption of both molecules decreased the affinity of the incoming GP and AMPA molecules to the surface, which leads to negative cooperative binding. This study provides the basis for a new analytical way to discriminate between Raman signals for GP and AMPA in soils, foods surface and groundwater samples to detect this herbicide.

Table 4. Adsorption parameters for glyphosate and AMPA on silver silicon capped nanopillars.

\begin{tabular}{cccc}
\hline & $K_{\mathrm{ads}}$ & $n$ & $R^{2}$ \\
\hline Glyphosate & $3.4 \times 10^{-6}$ & 0.50 & 0.976 \\
AMPA & $4.1 \times 10^{-6}$ & 0.68 & 0.997 \\
\hline
\end{tabular}




\section{Conclusions}

The adsorption and detection studies of glyphosate and its main metabolite aminomethylphosphonic acid on AgNPs have been carried out using the SERS method. The DFT-based theoretical simulations were employed to investigate the origin of the interaction between GP, AMPA and the Ag metal surface. The comparison between SERS and Raman scattering shows that the main interaction of glyphosate and AMPA with AgNPs surface is through the carboxylic and amine group from glyphosate and AMPA, respectively. In addition, both compounds adsorbed on AgNPs followed a negative cooperative binding mechanism evidenced by the adsorption constant and the cooperative constant values obtained. Finally, this study opens the possibility to develop a novel analytical way able to discriminate and identify food, soils and groundwater samples contaminated with GP and its metabolite AMPA.

\section{Acknowledgements}

We thank the Danish National Research Foundation (Project DNRF122) and Villum Fonden (Grant No. 9301) and Santo Tomas University (Project GIFQCAAMBECONP32017).

\section{References}

[1] Xu M, Gao Y, Li Y, Li X, Zhang H, Han X, Zhao B, and Su L. Indirect glyphosate detection based on ninhydrin reaction and surface-enhanced Raman scattering spectroscopy. Spectrochimica Acta Part A: molecular and biomolecular spectroscopy. 197: 78-82, 2018.

doi: 10.1016/j.saa.2018.01.014.

[2] Antier C, Kudsk P, Reboud X, Ulber L, Baret P, and Messéan A. Glyphosate use in the european agricultural sector. Sustainability. 12: 1-22, 2020. doi: 10.3390/su12145682.

[3] Helander M, Pauna A, Saikkonen K, and Saloniemi I. Glyphosate residues in soil affect crop plant germination and growth. Scientific reports. 9: 1-9, 2019.

doi: 10.1038/s41598-019-56195-3.

[4] Mañas F, Peralta L, Raviolo J, García H, Ugnia L, Gonzalez M, and Gorla N. Genotoxicity of AMPA, the environmental metabolite of glyphosate, assessed by the Comet assay and cytogenetic tests. Ecotoxicology and environmental safety. 72: 834-837, 2009. doi: 10.1016/j.ecoenv.2008.09.019.

[5] Corbera M, Hidalgo M, Salvad V, and Wieczorek P. Determination of glyphosate and aminomethylphosphonic acid in natural water using the capillary electrophoresis combined with enrichment step. Analytica chimica acta. 540: 3-7, 2005.

doi: 10.1016/j.aca.2004.12.028.

[6] Bruggen V, He M, Shin K, Mai V, Jeong K, Finckh M, and Morris J. Environmental and health effects of the herbicide glyphosate. Science of the total environment. 617:255-268, 2018.

doi: 10.1016/j.scitotenv.2017.10.309.

[7] Benachour N and Seralini G. Glyphosate formulations induce apoptosis and necrosis in human umbilical, embryonic, and placental cells. Chemical research in toxicology. 22: 97-105, 2009. 
doi: $10.1021 / \mathrm{tx} 800218 \mathrm{n}$.

[8] url: https://www.theguardian.com/environment/2019/sep/04/germany-ban-glyphosateweedkiller-by-2023.

[9] Zhang W, Feng Y, Ma L, An J, Zhang H, Cao M, Zhu H, Kang W, and Lian K. A method for determining glyphosate and its metabolite aminomethyl phosphonic acid by gas chromatography-flame photometric detection. Journal of chromatography. A.1589: 116121, 2019. doi: 10.1016/j.chroma.2018.12.039.

[10] Costa J, Ando R, Sant'Ana C, and Corio P. Surface-enhanced Raman spectroscopy studies of organophosphorous model molecules and pesticides. Physical chemistry chemical physics. 14: 15645-15651, 2012.

doi: $10.1039 / \mathrm{C} 2 \mathrm{CP} 42496 \mathrm{G}$.

[11] Frisch J, Trucks W, Schlegel B, Scuseria E, Robb A, Cheeseman R, Scalmani V, Mennucci B, Petersson A, Nakatsuji H, Caricato M, Li Hratchian X, Izmaylov F, Bloino J, Zheng G, Sonnenberg J, Hada M, Ehara M, Toyota K, Fukuda R, Hasegawa J, Ishida M, Nakajima T, Honda Y, Kitao O, Nakai H, Vreven T, Montgomery J, Peralta E, Ogliaro F, Bearpark M, Heyd J, Brothers E, Kudin K, Staroverov V, Kobayashi R, Normand J, Raghavachari K, Rendell A, Burant J, Iyengar S, Tomasi J, Cossi M, Rega N, Klene M, Ortiz J, Cioslowski J, and Fox D. Gaussian 09, revision a.1. Wallingford, CT. url: https://gaussian.com/g09citation/. 2009.

[12] Sharma G, Carmichael E, and Mccall D. Vibrational spectroscopy fabrication of SERS substrate for the detection of rhodamine 6G, glyphosate, melamine and salicylic acid. Vibrational spectroscopy. 83: 159-169, 2016.

doi: 10.1016/j.vibspec.2016.01.011.

[13] Torul H, Boyaci , and Tamer U. Attomole detection of glyphosate by surface-enhanced Raman spectroscopy using gold nanorods. Journal of pharmaceutical science. 35: 179184, 2010.

[14] Jin M, Hong Z, Chang M, Liu C, and Cheng H. Metal carbonyl-gold nanoparticle conjugates for highly sensitive SERS detection of organophosphorus pesticides. Biosensors and bioelectronics. 96: 167-172, 2017.

doi: 10.1016/j.bios.2017.05.005.

[15] Lopez-Ramirez M, Guerrini L, and Garcia-Ramos V. Vibrational analysis of herbicide diquat: a normal Raman and SERS study on Ag nanoparticles. Vibrational spectroscopy. 48: 58-64, 2008.

doi: 10.1016/j.vibspec.2007.12.003.

[16] Bonora S, Benassi E, Maris A, Tugnoli V, Ottani S, and Di Foggia M. Raman and SERS study on atrazine, prometryn and simetryn triazine herbicides. Journal of molecular structure. 1040: 139-148, 2013. doi: 10.1016/j.molstruc.2013.02.025.

[17] Feis A, Gellini C, Ricci M, Tognaccini L, Becucci M, and Smulevich G. Surface-enhanced Raman scattering of glyphosate on dispersed silver nanoparticles: a reinterpretation based on model molecules. Vibrational spectroscopy. 108: 1-8, 2020.

doi: 10.1016/j.vibspec.2020.103061. 
[18] Emonds G, Mignolet B, Malherbe C, Monbaliu J, Remacle F, and Eppe G. Understanding chemical interaction between phosphonatederivative molecules and silver surface cluster in SERS: a combined experimental and computational approach. Physical chemistry chemical physics. 21:22180-22187, 2019.

doi: 10.1039/C9CP01615E.

[19] Tu Q, Yang T, Qu Y, Gao S, Zhang Z, Zhang Q, Wang Y, Wang J, and He L. In situ colorimetric detection of glyphosate on plant tissues using cysteamine-modified gold nanoparticles. Analyst. 144: 2017-2025, 2019.

doi: 10.1039/C8AN02473A.

[20] Johnson P and Christy R. Optical constants of the noble metals. Physical review. B.6: 4370-4379, 1972. doi: 10.1103/PhysRevB.6.4370.

[21] Aspnes D and Studna D. Dielectric functions and optical parameters of Si, Ge, GaP, GaAs, GaSb, InP, InAs, and InSb from 1.5 to $6.0 \mathrm{eV}$. Physical review. B.27: 985-1009, 1983.

doi: 10.1103/PhysRevB.27.985.

[22] O'Boyle A, Tenderholt L, and Langner K. Cclib: a library for package-independent computational chemistry algorithms. Journal of computational chemistry. 29: 839-845, 2008.

doi: $10.1002 / j c c .20823$.

[23] Scott A and Radom L. Harmonic vibrational frequencies: an evaluation of HartreeFock, Moller-Plesset, quadratic configuration interaction, density functional theory, and semiempirical scale factors. Journal of physical chemistry. 100: 16502-16513, 1996. doi: 10.1021/jp960976r.

[24] Weiss J. The Hill equation revisited: uses and misuses. FASEB journal. 11: 835-841, 1997.

doi: 10.1096/fasebj.11.11.9285481.

[25] Castillo J, Rindzevicius T, Rozo C, and Boisen A. Adsorption and vibrational study of folic acid on gold nanopillar structures using surface-enhanced Raman scattering spectroscopy. Nanomaterials and nanotechnology. 5: 1-8, 2015. doi: 10.5772/61606.

[26] Ascolani J, Fuhr J, Bocan G, Millone A, Tognalli N, Santos M, and Martiarena M. Abiotic degradation of glyphosate into aminomethylphosphonic acid in the presence of metals. Journal of agricultural food chemistry. 62: 9651-9656, 2014.

doi: 10.1021/jf502979d.

[27] Tang J, Chen W, and Ju H. Rapid detection of pesticide residues using a silver nanoparticles coated glass bead as nonplanar substrate for SERS sensing. Sensors and actuators $b$ : chemical. 287: 576-583, 2019.

doi: 10.1016/j.snb.2019.02.084. 
Espectroscopia Raman Amplificada por Efecto de Superficie y Estudio con Teoría Funcional de Densidad para Glifosato y Ácido Aminometilfosfónico Utilizando Nanopilares de Silicio con Revestimiento de Plata

Resumen: El glifosato (GP) es un herbicida sistémico de amplio espectro que se utiliza para acabar con una amplia variedad de plantas dañinas. Varios estudios recientes indican posibles efectos adversos para la salud de los seres humanos. Este trabajo se centra en los estudios de detección y adsorción de GP y su metabolito ácido aminometilfosfónico (AMPA) en nanopilares de silicio con revestimiento de plata utilizando espectroscopía Raman amplificada por efecto de superficie (SERS). Se utilizó la Teoría Funcional de Densidad (DFT) con el funcional B3LYP para la optimización geométrica de las geometrías del estado fundamental y la simulación de los espectros Raman y SERS del GP y AMPA. Las vibraciones teóricamente calculadas y observadas experimentalmente de GP y AMPA libres y adheridas a la superficie de Ag exhibieron diferentes espectros Raman que revelan interacciones químicas entre las moléculas analizadas y la superficie del metal. Los estudios con DFT confirmaron que la principal interacción Ag-GP es con el oxígeno de los grupos carboxílico y fosfato, y para el AMPA la principal interacción es a través de una fuerte interacción entre el nitrógeno del $\mathrm{NH}$ y la superficie del metal. Para estudiar el comportamiento de unión, se realizaron análisis de isoterma de adsorción entre GP y AMPA en nanopilares de silicio con revestimiento de plata (AgNP). Finalmente, las isotermas obtenidas para GP y AMPA presentaron un mecanismo de unión cooperativo negativo.

Palabras Clave: Glifosato; AMPA; SERS; nanopilares de plata; adsorción; DFT. 
Espectroscopia Raman Amplificada por Superfície e Estudo da Teoria Funcional de Densidade para Glifosato e Ácido Aminometilfosfônico Usando Nanopilares de Silício com Cobertura de Prata

Resumo: O glifosato (GP) é um herbicida sistêmico de amplo espectro usado para matar uma grande variedade de plantas prejudiciais. Vários estudos recentes indicam possíveis efeitos adversos à saúde em humanos. Este trabalho está focado em estudos de detecção e adsorção de GP e seu metabólito ácido aminometilfosfônico (AMPA) em nanopilares de silício com cobertura de prata usando espectroscopia Raman amplificada por superfície (SERS). A Teoria Funcional de Densidade (DFT) com o funcional B3LYP foi empregada para a otimização da geometria do estado fundamental e simulação dos espectros Raman e SERS do GP e AMPA. As vibrações teoricamente calculadas e experimentalmente observadas de GP e AMPA livres e fixadas na superfície de Ag exibiram diferentes espectros Raman revelando interações químicas entre as moléculas analisadas e a superfície do metal. Estudos com DFT confirmaram que a principal interação Ag-GP é com o oxigênio dos grupos carboxílico e fosfato, e para AMPA a principal interação é através de uma forte interação entre o nitrogênio do $\mathrm{NH}$ com a superfície do metal. A fim de estudar o comportamento de ligação, foram realizadas análises de isoterma de adsorção entre GP e AMPA em nanopilares de silício com cobertura de prata (Ag NPs). Finalmente, as isotermas obtidas para GP e AMPA seguiram um mecanismo de ligação cooperativa negativa.

Palavras-chave: Glifosato; AMPA; SERS; nanopilares de prata; adsorção; DFT. 


\section{Ciro Rozo}

Chemist and MSc in chemist from Universidad Industrial de Santander with specialization in computational chemistry. Currently, he is associate professor in chemistry at Universidad Santo Tomas.

ORCID: 0000-0001-6241-3490

\section{Kaiyu Wu}

Bsc in Electrical Engineering and $\mathrm{PhD}$ in Nanotechnology from Denmark Technical University (DTU). Currently, he is researcher at the Department of Health Technology (DTU), with experience in fabrication of nanopillars and Raman scattering technique to build analytical devices.

ORCID: 0000-0002-5666-8419

\section{Tomas Rindzevicius}

$\mathrm{PhD}$ in plasmonics for sensing applications from Chalmers University of Technology (CUT). He has experience in commercializing nanotech inventions. Experience in nanoplasmonics, biosensing, spectroscopy and microscopy tools, nanofabrication, and surface-enhanced Raman scattering (SERS) and commercialisation of SERS substrates.

ORCID: 0000-0002-0712-1388

\section{Anja Boisen}

Anja Boisen is professor and head of Nanoprobes research group at department of Micro and Nanotechnology, Technical University of Denmark. Also, she is heading a DNRF and Villum Centre of Excellence named IDUN - Intelligent Drug Delivery and Sensing Using Microcontainers and Nanomechanics. She has thorough knowledge on micromechanics and nanotechnology. Her research group focuses on development and application of micro and nano mechanical sensors and microfabricated systems for oral drug delivery.

ORCID: 0000-0002-9918-6567

\section{John J. Castillo}

Chemist and Doctor in chemistry from Industrial University of Santander (Associate Professor) with a Postdoctorate in nanotechnology from Denmark Technical University. $\mathrm{He}$ is author and co-author of 33 specialized high impact journals and his research is focused on biosensors, bioelectronics and nanosciences.

ORCID: 0000-0002-6751-2305 